\title{
Spatial and temporal changes in fish yields and fish communities in the largest tropical floodplain lake in Asia
}

\author{
Bunyeth Chan ${ }^{1,2, *}$, Peng Bun Ngor ${ }^{1,4}$, Nam So ${ }^{4}$ and Sovan Lek ${ }^{1,3}$ \\ ${ }^{1}$ Laboratoire Evolution \& Diversité Biologique, UMR 5174, Université Paul Sabatier-ToulouseIII, 118routes de Narbonne, \\ 31062 Toulouse, France \\ ${ }^{2}$ Centre for Biodiversity Conservation, Faculty of Science, Royal University of Phnom Penh, Blvd Confederation of Russia, \\ 12000 Phnom Penh, Cambodia \\ 3 The University of Battambang, National Road 5, Sangkat Preaek Preah Sdach, Battambang City, Battambang Province, Cambodia \\ ${ }^{4}$ Fisheries Administration, \# 186, Preah Norodom Blvd., PO Box 582, Phnom Penh, Cambodia
}

Received: 6 February 2017; Accepted: 13 November 2017

\begin{abstract}
Although the Tonle Sap Lake is the largest natural inland lake in Southeast Asia, little is known about the spatio-temporal patterns of its composition and yields. The present paper aimed to investigate the temporal change of yields of the most dominant fish species and to evaluate the spatio-temporal changes in the fish community and the indicator species of assemblages. Fish catch data were collected from thirtythree fishing lots around the lake during the open season from October to May each year between 1994 and 2000. The fish yields were dominated by few commercial fishes: Channa micropeltes, Pangasianodon hypophthalmus, Channa striata, Cyclocheilichthys enoplos, Henicorhynchus spp., Barbonymus gonionotus, Micronema spp. and Trichopodus microlepis. The standard linear regression coefficients of the fish yields versus year were negative for all these commercial species except T. microlepis. Moreover, the total fish yields of the lake were temporally declined (standard coefficient $=-2.410$, adjusted $r^{2}=0.272$ ). Nonmetric multidimensional scaling of the fish assemblage data showed a clear opposition between northern assemblage and southern assemblage along the first axis, and the temporal pattern of the samples from 1994 to 1999 was explained by the second axis. The fish species assemblage from earlier years (1994 and 1995) was characterised by the abundance of all functional groups of black-white-grey fish species, but more recent years (1996-1999) were linked to white and grey functional groups, which was explained by a decrease in many black fishes.
\end{abstract}

Keywords: fishing lots / Tonle Sap Lake / indicative species / inland fisheries / fish yields

\section{Introduction}

The fish resource provides one of the primary sources of animal protein consumed worldwide, and income, especially for people in developing countries (Allan et al., 2005; Nelson, 2006; Welcomme et al., 2010). In developing countries, fish protein sources are mainly derived from the harvest of natural fish stocks, while those in developed countries are produced by recreational fisheries or aquaculture (Allan et al., 2005; Welcomme et al., 2010). Poor people in developing countries depend on the inland fisheries sources more than marine sources (McIntyre et al., 2016). Harvesting natural fish stock has rapidly increased in developing countries but decreased in developed countries (Allan et al., 2005). Overall, the global inland fish

\footnotetext{
*Corresponding author: bunyethchan@gmail.com
}

catch is reported to be increased because of an increase in the exploitation in Asia and Africa (FAO, 2014) and an increase in human population density (McIntyre et al., 2016).

The Mekong River Basin lies within the Indo-Burma Biodiversity Hotspot and is the second most diverse river system in the world (Ziv et al., 2012). It is also one of the most intensive and productive inland fisheries in the world, and the Mekong River has the second highest level of river fish biodiversity after the Amazon River (Baran et al., 2013). It provides food sources for millions of people in the region (Baran and Myschowoda, 2008; Baran et al., 2013). The Mekong capture fisheries made up two third of the inland fish production in the basin (Baran et al., 2007). The Mekong fisheries are not only important for capture fisheries but also the economic value (Baran and Myschowoda, 2008).

The Tonle Sap Lake (TSL) is a major natural reservoir in the Mekong River, and it is the largest natural inland lake in 
Southeast Asia (Chea et al., 2016) and a biodiversity hotspot and a World Heritage Biosphere Reserve (Lamberts, 2006). After the African Great Lakes, the TSL has the second highest freshwater fish biodiversity in the world (Baran et al., 2013), and it is one of the world's most productive fisheries and fish species-rich lakes (Arias et al., 2013). Furthermore, the TSL plays a crucial role in providing fish products and protein to nearly two million people in the region (Holtgrieve et al., 2013), especially the communities living in the Tonle Sap System that depend on natural resources of the lake (Lamberts, 2006; Kimmu and Sarkkula, 2008). Approximately half of Cambodian's population obtain benefits in both directly and indirectly from the TSL's fisheries resources (Keskinen et al., 2005). The lake is not only important for ecology but also for the socio-economic and livelihood (Lamberts, 2006).

In the Mekong River, intensive exploitation has not only been threatening large fishes, but also the overall catch and freshwater biodiversity in the region (Allan et al., 2005; Kano et al., 2013). Moreover, the overfishing in the Mekong River threaten the capture fisheries in the TSL because of the connection between the Mekong River and the TSL via the Tonle Sap River (TSR) (Allan et al., 2005). The overall catch has increased twice in the last decade (Baran et al., 2001), which has resulted from an increase in fishing activities, fishing effort and the use of modern and illegal fishing practice (Allan et al., 2005). Due to an intensive fishing, the large migratory fishes (e.g., catfish and carp) have been reported to be declined, and the overall catch is dominated by small cyprinid fishes (i.e., Henicorhynchus spp.), which accounted for $40 \%$ of the total captures (Allan et al., 2005).

The Tonle Sap fisheries are indiscriminate in that they exploit all types and size class of fish (McCann et al., 2015). Indiscriminate fishing is common in developing countries where fish provide the main source of dietary protein. Despites the intense pressure of fishing, fisheries of the Mekong River and the TSL are still productive. The short reproductive cycle of small fishes is believed to be the important factor influencing the fish production of the lake (Lamberts, 2006). The life-history trait is the ecological driver that affects the population response to fishing pressure (Hsieh et al., 2006). Moreover, the health the Mekong River and the TSL system remain good condition because the water regime and water quality are not much changed while the dam on the main Mekong River is not yet operated.

Ichthyological information for the TSL still lacks as little research has been conducted. Surveys of the fish fauna in the TSL are needed to better understand the fisheries, the fish community, and ecosystem function. By using annual fish catch data collected at thirty-three fishing lot from 1994 to 2000 , the objectives of the present work were (i) to investigate the temporal change of yields of the most dominant species and (ii) to evaluate the spatio-temporal changes in the fish community and the indicator species of assemblages.

\section{Materials and methods}

\subsection{Study area}

Studies were carried out in the TSL located in the northwest Cambodia. The TSL is connected to the Mekong River by the TSR (Arias et al., 2013), and the water flows in the
TSR contain two directions, namely, inflow and outflow. From May to October, water flows into the lake through the TSR due to a large volume of water from tropical monsoon rainfall combined with snowmelt from the Tibetan Plateau (Mekong River Commission, 2005). In contrast, the water flows out from the lake into the Mekong River from November to April as the water level in the river decreases (Campbell et al., 2006). Reverse flow resulted from the alteration of the water level between seasons (Mekong River Commission, 2005). Seasonal flooding benefits primary and secondary production and the surface area of the lake also varies between seasons as a result of alterations to the water regime (Holtgrieve et al., 2013).

\subsection{Data collection}

The TSL freshwater fish catch data were collected by the Mekong River Commission in collaboration with the Cambodian inland fisheries administration and financially supported by DANIDA (Danish international development agency) (Ly and VanZalinge, 1998). Data were collected from thirty-three fishing lots around the lake (Fig. 1). The sampling method was designed and approved by Department of Fisheries with technical supports from Mekong River Commission (MRC's) experts. At each fishing lot, samplings were conducted on a weekly basis (four times per month) from October 1994 to May 2000 by the provincial fisheries researchers and supervised by central fisheries researchers from the Cambodian Department of Fisheries. Data collectors were trained in the basic concepts of sampling, identification and data record. The operation of the fishing lot was performed using river barrages with U-shaped bag-nets for riverine fishing lots and arrow-shaped bamboo fence traps for the lake floodplain fishing lots. Sampling and other works for species composition were followed as the method used in the stationary trawl (Dai) fisheries (see in Halls et al., 2013). In each sample, if the catch per unit effort (CPUE) per lift is less than $10 \mathrm{~kg}$, fish were separated and identified. Subsampling is needed if the CPUE per lift is greater than $10 \mathrm{~kg}$ (Ly and VanZalinge, 1998). Fish were identified to species, except for nine taxa that were identified to genus for certain genera covering several species. Identification was based on the consultation with MRC experts following the keys in (Rainboth, 1996). To estimate the monthly catches by species in each fishing lot, the mean weight by species of samples were multiplied by the number of catch per month (Ly and VanZalinge, 1998). Then, an estimated fish catch for the fishing lot within an open season was carried out. A dataset of fish yields $(\mathrm{kg} / \mathrm{ha} /$ year), which were measured as a function of the estimated catch per fishing lot per season $(\mathrm{kg})$ divided by fishing lot area (ha) for a unit of time (year), was utilized for analyses. The water level was measured in the TSR (Prek Kdam).

\subsection{Statistical analyses}

A dot plot was used to create a rank-yields plot of fishes. Linear models were used to detect temporal trends in yields of the most dominant fish species, the total fish yields of the lake over the past six years, and the relationship between fish yields and coefficient of variation in the water level. 


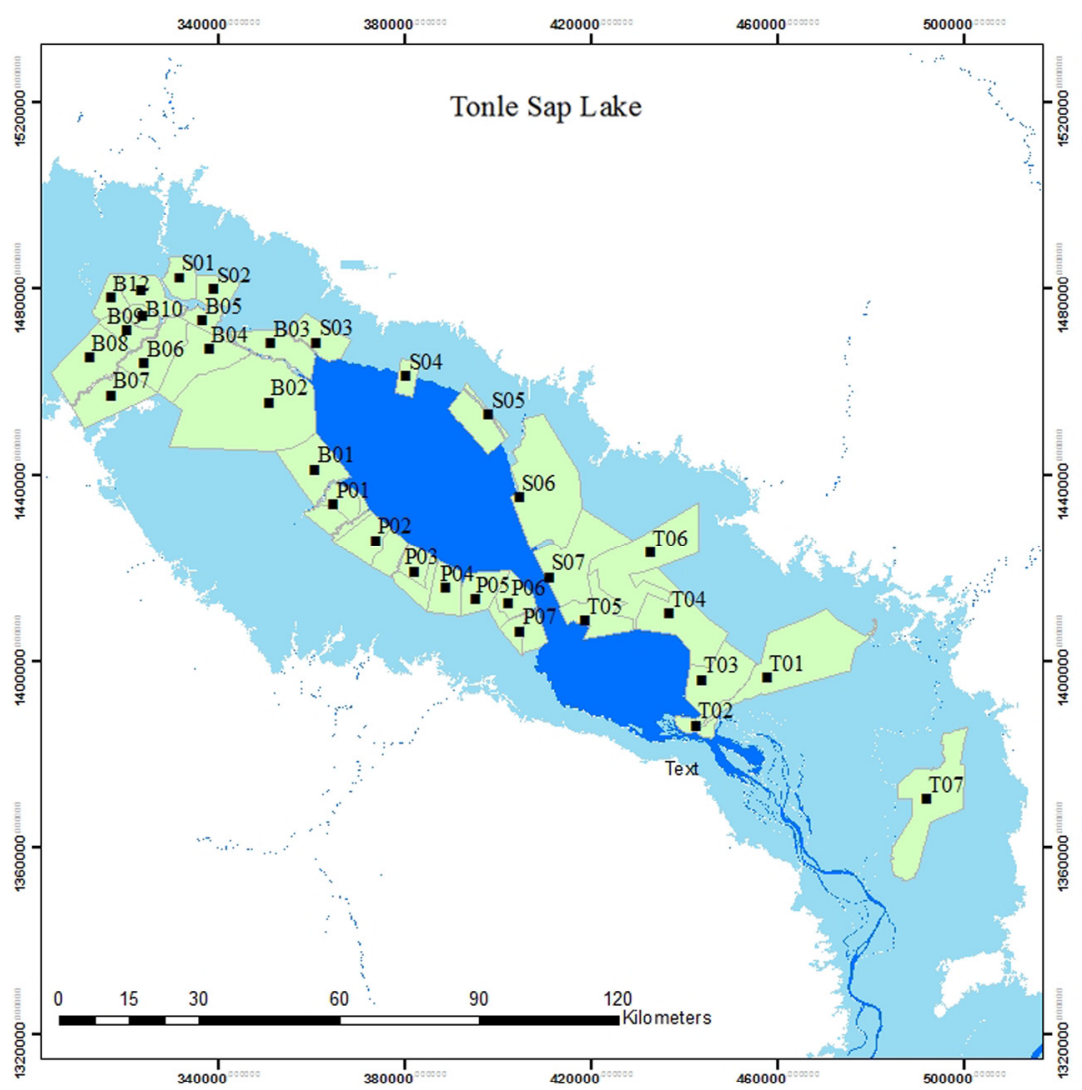

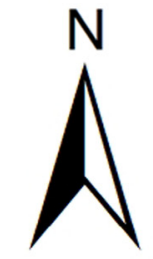

Legend
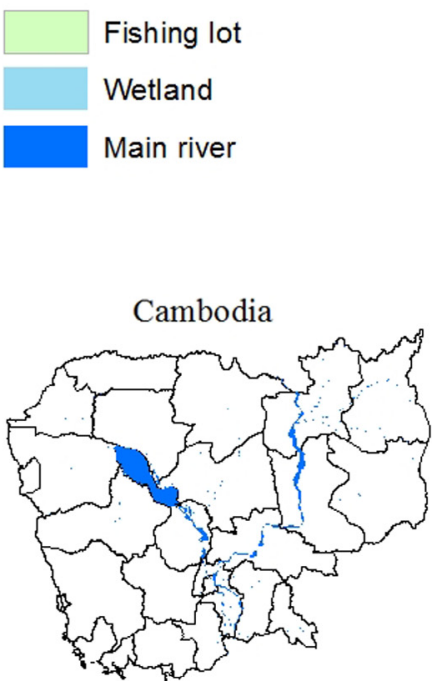

Fig. 1. Map showing the fishing lots surrounding the floodplain of the Tonle Sap Lake in Cambodia. "Wetland" refers to the flooded area during the wet season. The first letter in the code represents the province name: B (Battambang), S (Siem Reap), P (Pursat) and T (Kampong Thom) and is followed by the lot numbers in each province.

Non-metric multidimensional scaling (NMDS) ordination with the Bray-Curtis dissimilarity was used to reveal the spatio-temporal changes in the fish community by using the "metaMDS()" function from the vegan R-package (Oksanen et al., 2015). Hierarchical clustering based on the Euclidian dissymmetry distance on the NMDS scores with Ward linkage method allowed to identify the fish assemblages. Then, the cluster values were mapped using GIS to display the clustering results and the spatial distribution of fish yields around the TSL. A Mann-Whitney test was used to test for significant differences in fish yields and species richness between assemblages. Indicative species of assemblages were also defined using a multi-level pattern analysis index (R-package indicspecies, De Cáceres and Legendre, 2009).

All statistical analyses were performed using the $R$ program v.3.1.2 for Windows statistical software package (R Core Team, 2014).

\section{Results}

\subsection{Temporal trends of main commercial fishes, the lake's species richness, and fish yields}

The yields-species rank plot of fishes caught by fishing lots revealed eight dominant species (Fig. 2a) that accounted for 58\% of the overall fish yields from the lake: Channa micropeltes, Pangasianodon hypophthalmus, Channa striata, Cyclocheilichthys enoplos, Henicorhynchus spp., Barbonymus goniono- tus, Micronema spp. and Trichopodus microlepis. The standardized linear regression coefficients of fish yields versus year were negative (indicating a temporal decreasing trend in fish yields) for all species except T. microlepis (Tab. 1). Table 1 and Figure $2 \mathrm{~b}$ showed the significant decreasing trends in 3 species: C. micropeltes, Henicorhynchus spp., and Micronema spp. (negative standardized regression coefficient) and significantly increasing trend for $T$. microlepis (possitive standardized regression coefficient). Moreover, the linear model showed that the total fish yields of the lake were decreased between years (standard coefficient $=-2.410$, adjusted $r^{2}=0.272$, Fig. 2 c).

\subsection{The fish yields-flood pulse relationship}

Figure 3 showed that the fish yields are positively correlated with a coefficient of variation in the water level (adjusted $r^{2}=0.194$ ). The fish yields were increased with an increase in the water level fluctuation.

\subsection{Spatio-temporal variability in the fish community and its yields}

The ichthyofauna was composed of 76 fish species distributed across 28 families and nine orders. The NMDS ordination of the fish yields data provided a stress value of 0.154 , indicating a good ordination pattern. Hierarchical clustering of the NMDS scores revealed two assemblages: 


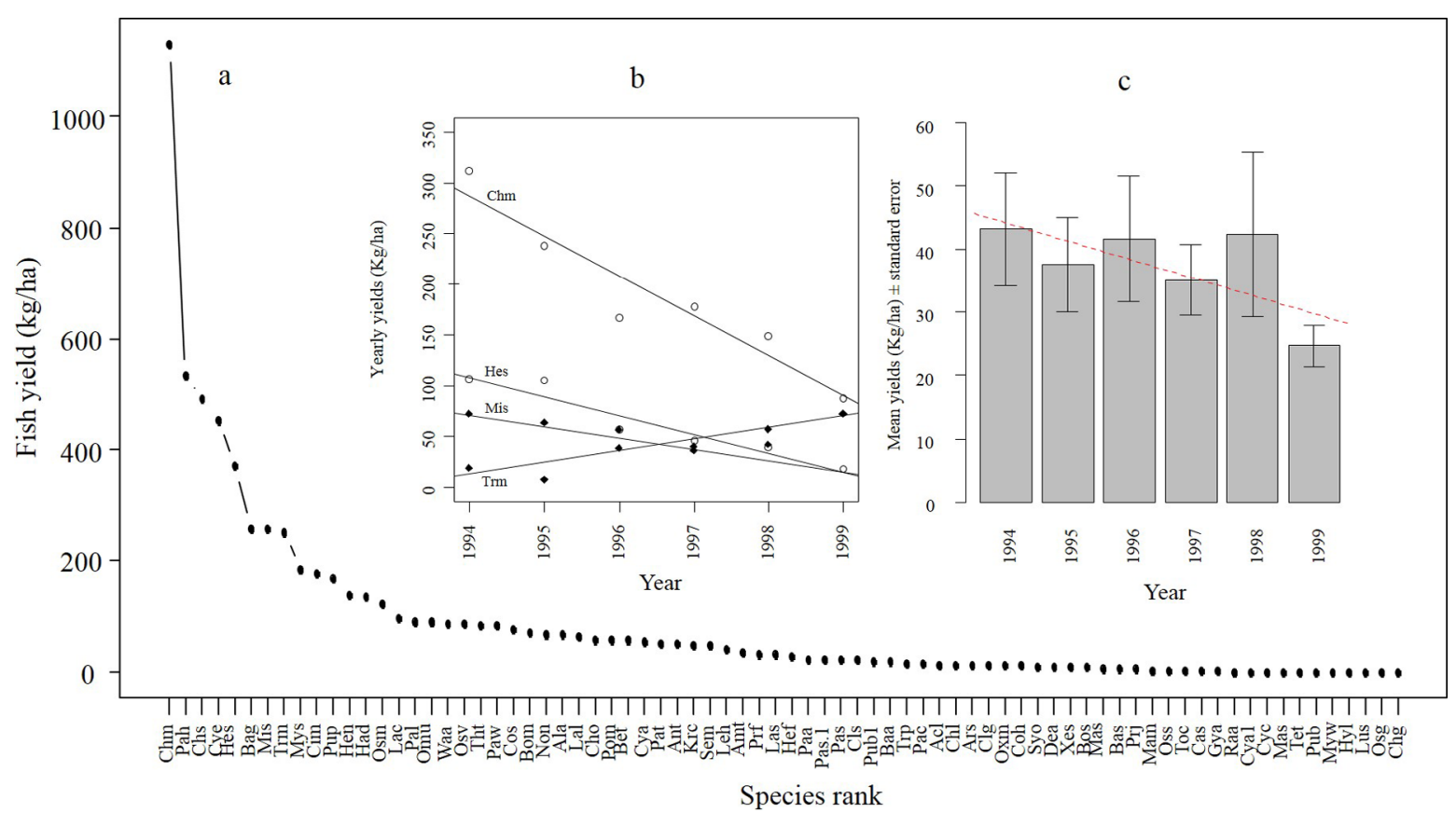

Fig. 2. (a) Decreasing rank-yields plot of fish in the Tonle Sap Lake caught by a fishing lot. (b) The significant temporal decrease/increase in the yields of four dominant species fitted by linear models. (c) Mean yields \pm standard error showing he temporal change in total fish yields. Abbreviations are as follows: Chm: Channa micropeltes, Hes: Henicorhynchus spp., Mis: Micronema spp. and Trm: Trichopodus microlepis.

Table 1. Results of the linear regression showing temporal changes in the yields of eight dominant fishes from 1994 to 2000 with the standard linear regression coefficient, the coefficient of determination and the $p$-values.

\begin{tabular}{llll}
\hline Taxa & $\begin{array}{l}\text { Standard } \\
\text { coefficient }\end{array}$ & $\begin{array}{l}\text { Adjusted } \\
r^{2}\end{array}$ & $p$-value \\
\hline Channa micropeltes & -6.074 & 0.877 & 0.003 \\
Pangasianodon hypophthalmus & -1.838 & 0.322 & 0.139 \\
Channa striata & -0.997 & 0.198 & 0.375 \\
Cyclocheilichthys enoplos & -0.658 & 0.097 & 0.546 \\
Henicorhynchus spp. & -6.874 & 0.902 & 0.002 \\
Barbonymus gonionotus & -0.559 & 0.072 & 0.606 \\
Micronema spp. & -4.578 & 0.799 & 0.010 \\
Trichopodus microlepis & 3.396 & 0.678 & 0.027 \\
\hline
\end{tabular}

northern assemblage (AN), mostly located in the north of the lake, and southern assemblage (AS) primarily found in the sites of the south (Fig. 4b). The NMDS ordination map revealed opposition between these two fish assemblages along the first axis of the ordination plane (Fig. 4a). The black fishes were mostly associated with $\mathrm{AN}$, except $C$. micropeltes, Channa lucius and Macrognathus siamensis which were linked to AS. White and grey fishes had wide range distribution covering both AN and AS and the estuarine fishes were only present in AS. Additionally, AN was primarily composed of the grey fish $C$. apogon, and AS was mostly consisting of the estuarine fish Hyporhamphus limbatus, the black fish $M$. siamensis, the grey fish Mystus wolffii and four white fishes: Devario aequipinnatus, Clupeichthys goniognathus, Botia

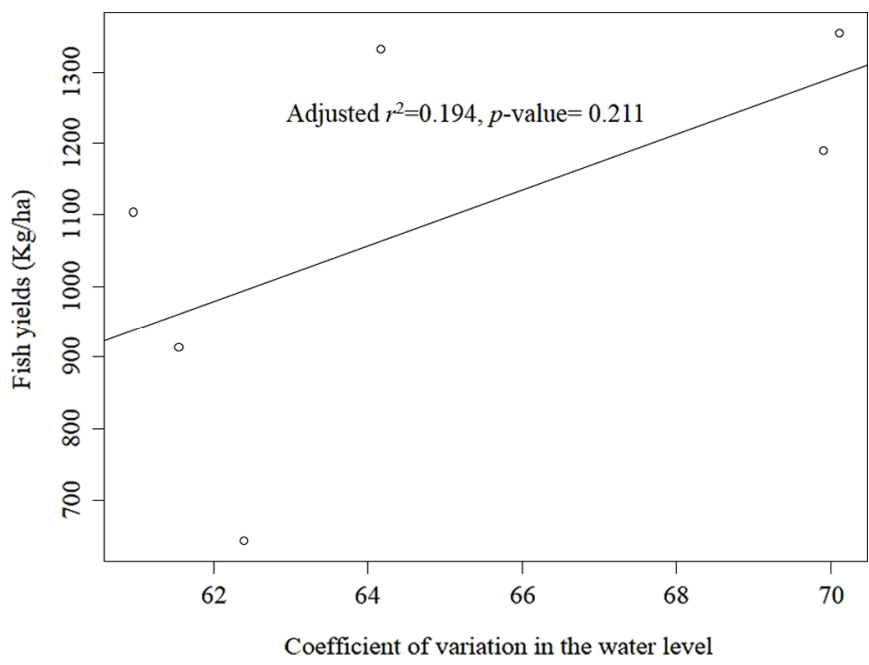

Fig. 3. Plot showing the correlation between fish yields and the coefficient of variation in the water level.

spp. and Labiobarbus siamensis (Fig. 4a). Also, the multi-level pattern analysis index revealed 36 indicative species for both assemblages: 3 in AN and 33 in AS. The indicator species for AN were gourami, T. microlepis, the climbing perch, Anabas testudineus, and Trichopodus pectoralis, all of which were black fishes. AS comprised 33 indicative species that were dominated by 19 species of white fishes followed by grey, estuarine and black fishes with 7, 5 and 2 species, respectively (see details in Tab. 2). Moreover, the AS fish yields and species richness were significantly higher than those of AN (MannWhitney test, $W=1032, p<0.001$, Fig. $4 c$ and $W=920$, $p<0.001$, Fig. 4d, respectively). 


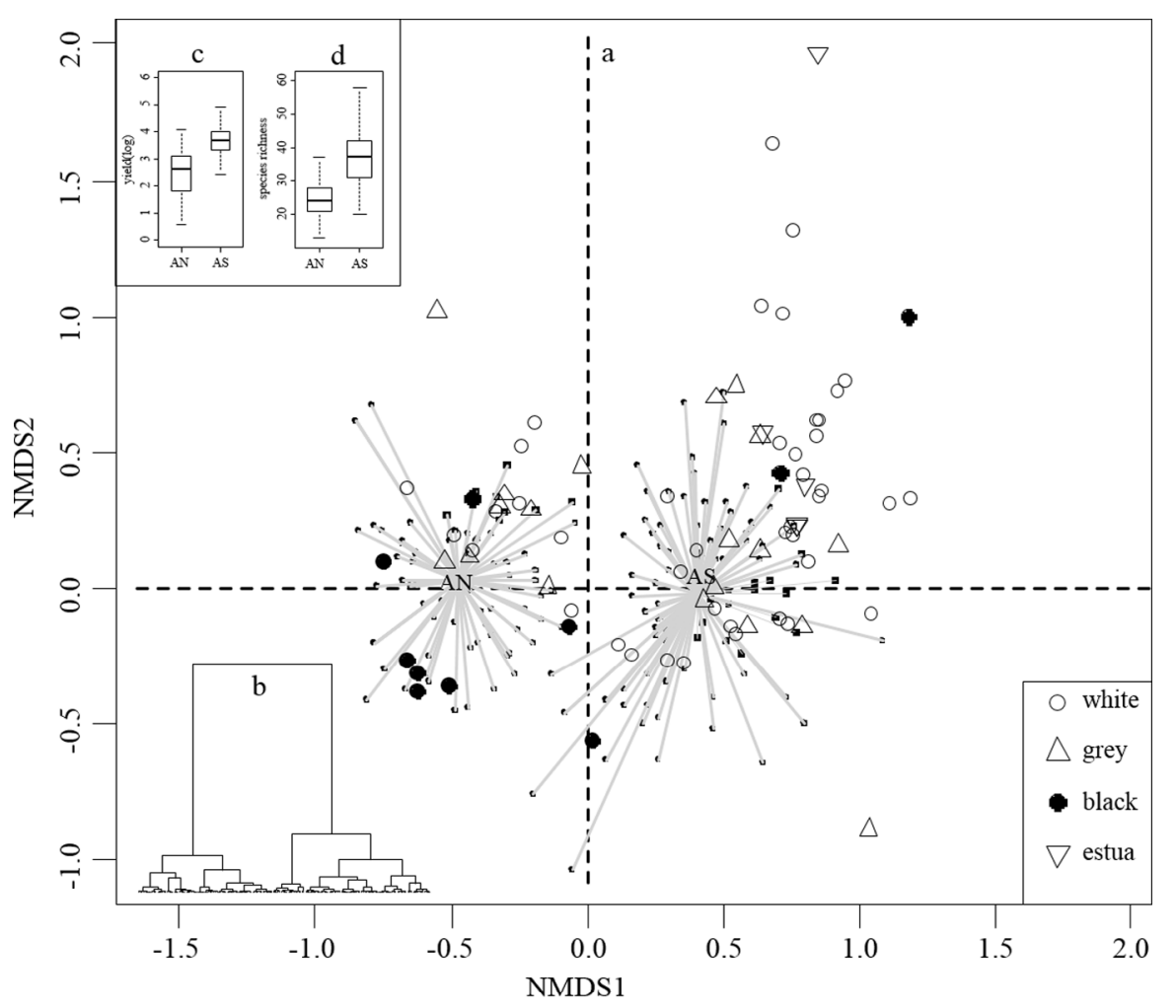

Fig. 4. (a) Non-metric multidimensional scaling (NMDS) ordination of 172 samples in the Tonle Sap Lake showing the spatial distribution of samples and species in two assemblages: AN and AS. (b) Hierarchical clustering dendrogram of the NMDS scores using the Euclidian similarity matrix and Ward agglomeration method. (c) Boxplot representing the median (-) and 25th and 75th percentiles of fish yields (kg/ha/year) at logarithm scale in both assemblages and (d) Boxplot representing the median (-) and 25th and 75th percentiles of species richness.

Figure 5a revealed a temporal change in the samples along the second axis from 1994 to 1999. Fish species from earlier years (1994 and 1995) were correlated with the negative values of axis 2 and determined by the abundance of all black-whitegrey fish functional groups. However, the species from the recent years (1996-1999) are in the positive part of axis 2 and linked to white and grey functional group species (Fig. 5a). The distribution patterns of four fishing lots, namely S01, S02, $\mathrm{S} 03$, and P01, changed from AS to AN (Fig. 5b-d). These shifts occurred in the fishing lots located along the border between these two assemblages.

\section{Discussion}

\subsection{Temporal trends in fish yields of the main commercial fishes and total fish yields of the lake}

The results suggested that the lake was dominated by few commercial fish species. Community composition follows the rule that a few species are highly abundant, many species are moderately abundant, and the remaining few species are rare (Welcomme, 1999). Similarly, Sverdrup-Jensen (2002) found that few common species dominate the TSL. C. striata were found to be the most common snakehead in Cambodia (Rainboth, 1996) and distributed throughout the TSL (Chheng et al., 2005). C. micropeltes was found to be the second most dominant species in Cambodia (Chheng et al., 2005), and it is one of the ten most important fishes in the TSL (Enomoto et al.,
2011). Henicorhynchus spp. were the most important group regarding fisheries output for the Lower Mekong Basin (Poulsen et al., 2002), and they accounted for $50 \%$ of the total annual catch of the Dai fisheries in the TSR (Halls et al., 2013). Additionally, Lim et al. (1999) explained that the TSL floodplain and the inundated forest were of significant importance for supporting large fish species because these species use this area for reproduction, feeding and spawning activities. Among the eight most important fishes, six species (except $C$. micropeltes and $C$. striata) were herbivorous, and this was the most dominant group in the lake. Herbivorous fishes were common in the inundated forest as they come to forage on the zoobenthic community (Lim et al., 1999).

The result contributed to provide evidence that the yields of some dominant fishes and the total fish yields have declined. Here, we discuss the fishing pressure as treatment effect on the decrease in the yields of the main commercial fishes. Fishing has a direct impact on the decline in fish population (Pauly et al., 2002; Hsieh et al., 2006). Overharvesting fish stock remains an intense pressure and result in the fisheries resources declined (Cooke and Cowx, 2004; Anderson et al., 2008; McIntyre et al., 2016). Furthermore, besides the large commercial fishing (i.e., fishing lot operation and Dai fisheries), the mobile gear fishing at the family level is also presented in the TSL (Bonheur and Lane, 2002). The large fish species are the primary target of catching by local fishers due to their high economic price in the market (Enomoto et al., 2011). At first, 
Table 2. The summary of the indicator species in each assemblage with the statistical and $p$-values.

\begin{tabular}{llll}
\hline Species & $\begin{array}{l}\text { Functional } \\
\text { group }\end{array}$ & $\begin{array}{l}\text { Statistic- } \\
\text { value }\end{array}$ & $\begin{array}{l}p \text { - } \\
\text { value }\end{array}$ \\
\hline
\end{tabular}

Northern assemblage (AN): 3 species

$\begin{array}{llll}\text { Trichopodus microlepis } & \text { Black } & 0.924 & 0.005 \\ \text { Anabas testudineus } & \text { Black } & 0.891 & 0.005 \\ \text { Trichopodus pectoralis } & \text { Black } & 0.692 & 0.005\end{array}$

Southern assemblage (AS): 33 species

\begin{tabular}{llll} 
Parambassis wolffi & Grey & 0.927 & 0.005 \\
Pangasianodon hypophthalmus & White & 0.917 & 0.005 \\
Chitala ornata & Grey & 0.906 & 0.005 \\
Cirrhinus microlepis & White & 0.901 & 0.005 \\
Boesemania microlepis & Grey & 0.899 & 0.005 \\
Wallago attu & White & 0.897 & 0.005 \\
Belodontichthys truncatus & White & 0.892 & 0.005 \\
Micronema spp. & Grey & 0.88 & 0.005 \\
Labeo chrysophekadion & Grey & 0.864 & 0.005 \\
Setipinna melanochir & Estuarine & 0.859 & 0.005 \\
Polynemus multifilis & Estuarine & 0.825 & 0.005 \\
Pangasius larnaudii & White & 0.815 & 0.005 \\
Albulichthys albuloides & White & 0.786 & 0.005 \\
Amblyrhynchichthys truncates & White & 0.751 & 0.005 \\
Coilia spp. & Estuarine & 0.722 & 0.005 \\
Leptobarbus rubripinna & White & 0.691 & 0.005 \\
Probarbus jullieni & White & 0.676 & 0.005 \\
Arius spp. & White & 0.668 & 0.005 \\
Pangasius spp. & White & 0.66 & 0.005 \\
Hemibagrus filamentus & White & 0.632 & 0.005 \\
Cosmochilus harmandi & White & 0.601 & 0.005 \\
Parambassis apogonoides & Grey & 0.574 & 0.005 \\
Achiroides leucorhynchos & White & 0.495 & 0.005 \\
Labiobarbus siamensis & White & 0.473 & 0.005 \\
Channa lucius & Black & 0.404 & 0.005 \\
Catlocarpio siamensis & White & 0.399 & 0.005 \\
Mastacembelus spp. & Black & 0.393 & 0.005 \\
Macrochirichthys macrochirus & White & 0.386 & 0.005 \\
Systomus rubripinnis & Grey & 0.385 & 0.01 \\
Bagarius spp. & White & 0.372 & 0.005 \\
Botia spp. & White & 0.372 & 0.005 \\
Toxotes chatareus & Estuarine & 0.357 & 0.005 \\
Tenualosa thibaudeaui & Estuarine & 0.326 & 0.005 \\
\hline & & & \\
& & & \\
& & &
\end{tabular}

when the ecosystem is healthy, the fishermen prefer to harvest the large fishes. It is called "fishing down the food web" phenomenon (Pauly et al., 1998). Later, fishers catch all kind and size class of fish. The catch in the manner that all fish species and size class across the food webs were exploited is called the indiscriminate fishing (McCann et al., 2015). Fishing has a direct influence on alteration of the fisheries production, fish composition and community, and ecosystem functioning (Anderson et al., 2008). Lamberts (2006) said that, in the TSL, due to the intensive pressure of fishing, the decline of the large fish species in the catch was found, and the catch was dominated by the small fishes with the short reproductive cycle. Fishing could alter the fish community and caused an increase in the abundance of small fishes with rapid population growth (McCann et al., 2015).

The yields of $T$. microlepis increased in the recent years while the yields of the carnivorous $C$. micropeltes declined. In the ecosystem, $C$. micropeltes is the top predator, and $T$. microlepis serve as prey. An increase in T. microlepis yields could be a result of a decrease in predatory fishes, especially $C$. micropeltes. The loss of predators could alter the community structure so that small prey fish became dominant. This result is consistent with those of previous studies stating that the TSL fisheries are now dominated by small fishes while large fishes have declined (Enomoto et al., 2011). Moreover, catch of opportunistic species or small white fishes in the Mekong fishery was recorded (Cooperman et al., 2012). For instance, the catch of Henicorhynchus spp. represented $50 \%$ of the Dai fishery in the TSR (Halls et al., 2013).

Among the eight most dominant species, P. hypophthalmus, C. enoplos, Henicorhynchus spp., and B. gonionotus undertake long migrations within the Lower Mekong Basin (Rainboth, 1996; Zalinge et al., 2003). Moreover, Halls et al. (2013) stated that these migratory species are challenged by the barrage system of river-spanning fences for Dai fishery in the TSR. Moreover, Enomoto et al. (2011) illustrated that $C$. micropeltes are caught to be raised in fish farming around the TSL.

The results suggested that the total fish yields of the lake were temporally decreased. Jackson et al. (2001) stated that the sustainable fisheries have rarely been found. Additionally, Allan et al. (2005) illustrated that the catch per fisherman, in the Tonle Sap System, had declined 50\%. Moreover, overfishing in inland waters is occurring (Allan et al., 2005) and exploitation of fish stock appeard to have an adverse impact on the world's inland aquatic resource (McIntyre et al., 2007, 2016; Welcomme et al., 2010). In the TSL, the overfishing is reported to be the major factor affecting the total fish catch volume (Lamberts, 2006).

\subsection{Relationship between fish yields and flood pulse}

The results suggested that the fish yields are positively correlated with the water level fluctuation. The result is consistent with a previous study stating that the fish catch is positively linked with the flood index in the Cross River floodplain ecosystem, Nigeria (Moses, 1987). The level and duration of flood influenced the breeding, growth, and survival of fish (Welcomme, 1999). The seasonal flood pulse appeared to be the key factor affecting the fisheries resources in the TSL (Lamberts, 2006). Seasonal flooding benefits primary and secondary production (Holtgrieve et al., 2013). Moreover, the fish catch, in the floodplain system, was correlated with the flooding in the previous years (Allan et al., 2005).

\subsection{Spatial and temporal change in fish communities and its yields}

The north of the lake is covered by a wetland area comprising a large flooded forest, a shrub forest and vegetation cover such as water hyacinth (Enomoto et al., 2011). Black fishes are non-migratory, and they inhabit the lakes or swamps during the dry season and migrate to the flooded areas during 

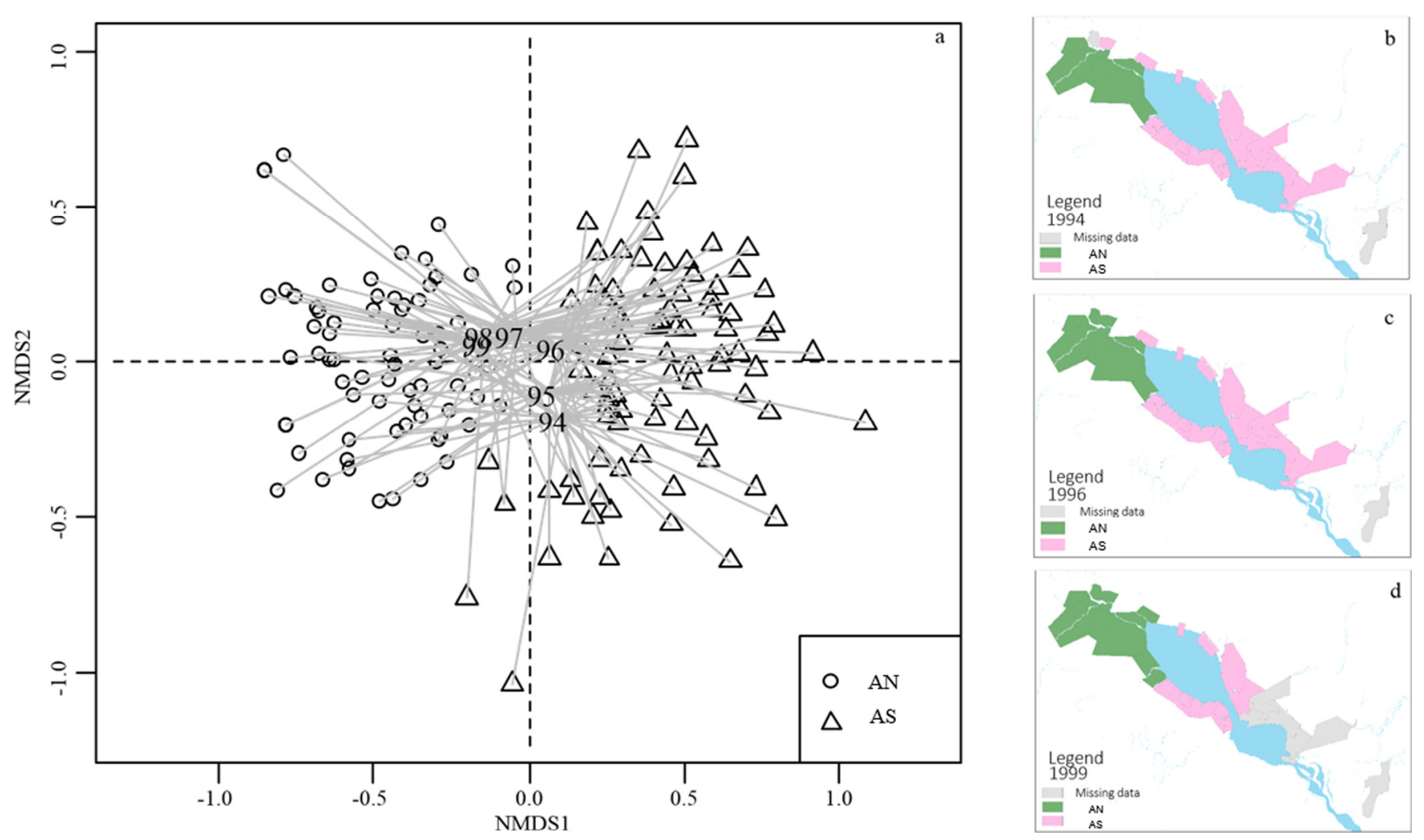

Fig. 5. (a) The NMDS ordination map showing the temporal distribution pattern of samples from 1994 to 1999. (b) A map of the Tonle Sap Lake showing the distribution of samples based on the assemblage identified by hierarchical clustering analysis in 1994, (c) in 1996 and (d) in1999. The green area represents AN, and the pink represents AS; grey indicates missing data.

the wet season (Campbell et al., 2006). Although AN was mainly composed of grey fish $C$. apogon, the important indicator species of the assemblage were $T$. microlepis, the climbing perch, A. testudineus, and T. pectoralis. These three fishes were black fishes that migrate between the lake and the floodplain (Halls et al., 2013) and they spend most of their lifespans in the flooded forest (Campbell et al., 2006). As stated above, the northern part of the lake covers includes an area with a large flooded forest containing healthy habitats for these black fishes. T. microlepis prefer inhabiting the areas containing vegetation cover (Lamberts, 2001). Furthermore, the results suggested that estuarine fishes were only present in $\mathrm{AS}$, and the number of indicator species of AS was also higher than those in AN. This high species richness, a large number of indicator species, and large fish yields appeared to be impacted by hydrological and geographical factors.

Lim et al. (1999) stated that when the water level decreased, the migratory fishes move from the lake to the Mekong River, and they migrate back to the lake at the beginning of the rainy season. The migration of fish appeared to be the main factor that resulted in the high amount of fish captured in the inlet-outlet area of the lake (Enomoto et al., 2011). Therefore, it is logical that this area had a significant number of indicator species and high fish yields. White fishes undergo a long migration from the lake to the tributaries of the Mekong River (Zalinge et al., 2003). Most of the species that live in the Mekong River migrate to the lake during the rainy reason to reproduce; they spawn from May-August, likely move from the floodplain to the river in October, and migrate back in April or May (Lim et al., 1999). This migration occurs during the open fishing season, so migratory species were captured during the study period. The biological effects of streams appeared to be the key determinant that may influence the spatial change in the fish communities. The watershed for the southern part of the lake is larger than that of the north with a sureface area of $30098 \mathrm{~km}^{2}$ and $20184 \mathrm{~km}^{2}$, respectively (Nguyen et al., 2008). Furthermore, Vanni et al. (2006) illustrated that the watershed area and the tributaries are the primary sources of the lake's nutrients, which were observed to be the main factors influencing fish production.

\section{Conclusion}

Based on the catch data from the fishing lot from 1994 to 2000 , our study showed that the lake was dominated by few commercial fish species: $C$. micropeltes, $P$. hypophthalmus, $C$. striata, C. enoplos, Henicorhynchus spp., B. gonionotus, Micronema spp. and T. microlepis. All these dominant fishes were temporally declined, except $T$. microlepis. We noticed that the large fish species were temporally decreased and small fish species increased. Catching the larger fishes should be considered and balanced. Removal of the largest fish species that are the top predators could have a substantial top-down effect on food web dynamics. The lack of consideration on large fish harvesting could have an adverse impact on the fish community and lead unstable population change (Anderson et al., 2008). Additionally, total fish yields of the lake were 
temporally declined. Balanced harvesting is recommended because it could reduce the ecological effects of fishing on components of the ecosystem. Also, the water fluctuation is a key driver characterizing the fish yields of the lake. The results showed the spatial and temporal changes in the fish communities and fish yields present in the TSL. Here, the Tonle Sap fish communities are divided into two assemblages: AS and AN. The fish yields, species richness and indicator species of the AS were significantly higher than those of AN. Thus, the AS is the potential area for both yields and species richess where should be considered for protected area. Indicator species indicated the diversity of other species, taxa or communities within an area. This information is of importance that could be used in making the decision for the particular area protection.

Acknowledgements. The first author would like to express gratitude to the Erasmus Mundus program (Lotus+ project) for providing a scholarship included school fee and monthly support. The authors also wish to acknowledge the Belmont TLSCC project that supports fund for research. The manuscript has been greatly improved by insightful comments of two anonymous reviewers. Also, we are grateful to the MRC for providing statistical data. We also express appreciation to the Laboratoire Evolution \& Diversité Biologique (EDB)-Université Paul Sabatier-Toulouse3 for supporting equipment. EDB lab was supported by "Investissement d'Avenir" grants (CEBA, ref. ANR-10-LABX-0025; TULIP, ref. ANR-10LABX-41).

\section{References}

Allan JD, Abell R, Hogan Z, et al. 2005. Overfishing of inland waters. Bioscience 55: 1041-1051.

Anderson CNK, Hsieh C, Sandin SA, et al. 2008. Why fishing magnifies fluctuations in fish abundance. Nature 452: 835-839.

Arias ME, Cochrane TA, Norton D, Killeen TJ, Khon P. 2013. The flood pulse as the underlying driver of vegetation in the largest wetland and fishery of the Mekong Basin. Ambio 42: 864-876.

Baran E, Myschowoda C. 2008. Dams and fisheries in the Mekong Basin. Aquat Ecosyst Health Manag 12: 227-234.

Baran E, Zalinge NV, Ngor PB, Baird I, Coates D. 2001. Fish resource and hydrobiological modelling approaches in the Mekong Basin. Penang, Malaysia/Phnom Penh, Cambodia: ICLARM/Mekong River Commission Secretariat, $60 \mathrm{p}$.

Baran E, Jantunen T, Kieok CC. 2007. Value of inland fisheries in the Mekong River Basin. Phnom Penh, Cambodia: World Fish Centre, $76 \mathrm{p}$.

Baran E, So N, Degen P, Chen X-Y., Star P. 2013. Updated information on fish and fisheries in the Mekong Basin. Catch Cult 19: 24-25.

Bonheur N, Lane BD. 2002. Natural resources management for human security in Cambodia's Tonle Sap biosphere reserve. Environ Sci Policy 5: 33-41.

Campbell IC, Poole C, Giesen W, Valbo-Jorgensen J. 2006. Species diversity and ecology of Tonle Sap Great Lake, Cambodia. Aquat Sci 68: 355-373.

Chea R, Guo C, Grenouillet G, Lek S. 2016. Toward an ecological understanding of a flood-pulse system lake in a tropical ecosystem: food web structure and ecosystem health. Ecol Model 323: 1-11.

Chheng P, Touch BT, Baran E, Leng SV. 2005. Biological reviews of important Cambodian fish species, based on FishBase 2004. Inland
Fisheries Research and Development Institute (IFReDI). Phnom Penh. 122 p.

Cooke SJ, Cowx IG. 2004. The role of recreational fishing in global fish frises. Bioscience 54: 857-859.

Cooperman MS, So N, Arias M, et al. 2012. A watershed moment for the Mekong: newly announced community use and conservation areas for the Tonle Sap Lake may boost sustainability of the world's largest inland fishery. Cambodian J Nat Hist 2012: 101-106.

De Cáceres M, Legendre P. 2009. Associations between species and groups of sites: indices and statistical inference. Ecology 90: 35663574.

Enomoto K, Ishikawa S, Hori M, et al. 2011. Data mining and stock assessment of fisheries resources in Tonle Sap Lake. Cambodia Fish Sci 77: 713-722.

FAO. 2014. The state of world fisheries and aquaculture. Rome: Food and Agriculture Oranization of the United Nations, 223 p.

Halls AS, Paxton BR, Hall N, et al. 2013. The stationary trawl (Dai) fishery of the Tonle Sap Great Lake system, Cambodia, MRC Technical Paper No. 32. Mekong River Commission. Phnom Penh, Cambodia, $168 \mathrm{p}$.

Holtgrieve GW, Arias ME, Irvine KN, et al. 2013. Patterns of ecosystem metabolism in the Tonle Sap Lake, Cambodia with links to capture fisheries. PLoS One 8: e71395.

Hsieh C, Reiss CS, Hunter JR, Beddington JR, May RM, Sugihara G. 2006. Fishing elevates variability in the abundance of exploited species. Nature 443: 859-862.

Jackson JB, Kirby MX, Berger WH, et al. 2001. Historical overfishing and the recent collapse of coastal ecosystems. Science 293: 629637.

Kano Y, Adnan MS, Grudpan C, et al. 2013. An online database on freshwater fish diversity and distribution in Mainland Southeast Asia. Ichthyol Res 60: 293-295.

Keskinen M, Koponen J, Kummu M, Nikula J, Sarkkula J, Varis O. 2005. Integration of socio-economic and hydrological information in the Tonle Sap Lake, Cambodia. In: Kachitvichyanukul V, Purintrapidan U, Utayopas P (eds.), International Conference on Simulation and Modeling, $7 \mathrm{p}$.

Kimmu M, Sarkkula J. 2008. Impact of the Mekong River flow alteration on the Tonle Sap flood pulse. Ambio 37: 185-192.

Lamberts D. 2001. Tonle Sap fisheries: a case study on floodplain gillnet fisheries in Siem Reap, Cambodia. FAO regional Office for Asia and the Pacific. Bangkok, Thailand, 50 p.

Lamberts D. 2006. The Tonle Sap Lake as a productive ecosystem. Int $J$ Water Resour Dev 22: 481-495.

Lim P, Lek S, Touch ST, Mao S, Chhouk B. 1999. Diversity and spatial distribution of freshwater fish in Great Lake and Tonle Sap river (Cambodia, Southeast Asia). Aquat Living Resour 12: 379-386.

Ly S, VanZalinge NP. 1998. Catch statistics of Cambodian freshwater fisheries1994-1997, report for project: the management of the freshwater capture fisheries of Cambodia phase1. Phnom Penh, Cambodia: Mekong River Commission, 148 p.

McCann KS, Gellner G, McMeans BC, et al. 2015. Food webs and the sustainability of indiscriminate fisheries 1. Can J Fish Aquat Sci 665: 656-665.

McIntyre PB, Jones LE, Flecker AS, Vanni MJ. 2007. Fish extinctions alter nutrient recycling in tropical freshwaters. Proc Natl Acad Sci 104: 4461-4466.

McIntyre PB, Reidy Liermann CA, Revenga C. 2016. Linking freshwater fishery management to global food security and biodiversity conservation. Proc Natl Acad Sci USA 113: 12880 12885.

Mekong River Commission. 2005. Overview of the hydrology of the Mekong Basin. Vientiane: Mekong River Commission, 73 p. 
Moses BS. 1987. The influence of flood regime on fish catch and fish communities of the Cross River floodplain ecosystem, Nigeria. Environ Biol Fish 18: 51-65.

Nelson JS. 2006. Fishes of the world, 4th ed. Hoboken, New Jersey: John Wiley \& Sons, Inc., $601 \mathrm{p}$.

Nguyen TH, Sunada K, Oishi S, Sakamoto Y. 2008. The spatial distribution of fish species catches in relation to catchment and habitat feature in the floodplain lot fisheries of Tonle Sap Lake, Cambodia. J Fish Aquat Sci 3: 213-227.

Oksanen J, Blanchet FG, Kindt R, et al. 2015. Vegan: community ecology package. R package version 2. 3-0.

Pauly D, Christensen V, Dalsgaard J, Froese R, Torres Jr. F. 1998. Fishing down marine food webs. Science 279: 860-863.

Pauly D, Christensen V, Guénette S, et al. 2002. Towards sustainability in world fisheries. Nature 418: 689-695.

Poulsen AF, Ouch P, Viravong S, Suntornratana U, Nguyen TT. 2002. Fish migrations of the Lower Mekong River Basin: implications for development. Phnom Penh: Planning and environmental management.

R Core Team. 2014. R: language and environment for statistical computing. Vienna, Austria. http://www.R-project.org/.
Rainboth WJ. 1996. FAO species identification field guide for fishery purposes: fish of the Cambodian Mekong. Food and Agriculture Oranization (FAO) of the United Nations. Rome, Italy, 265 p.

Sverdrup-Jensen S. 2002. Fisheries in the Lower Mekong Basin: status and perspectives. MRC Technical Paper No 6. Mekong River Commission (MRC). Phnom Penh, 103 p. ISSN: 1683-1489.

Vanni MJ, Bowling AM, Dickman EM, et al. 2006. Nutrient cycling by fish supports relatively more primary production as lake productivity increase. Ecology 87: 1696-1709.

Welcomme RL. 1999. A review of a model for qualitative evaluation of exploitation levels in multi-species fisheries. Fish Manag Ecol 6: 1-19.

Welcomme RL, Cowx IG, Coates D, et al. 2010. Inland capture fisheries. Philos Trans R Soc Lond B: Biol Sci 365: 2881-2896.

Zalinge N. van, Loeung D, Ngor PB, Sarkkula J, Koponen J. 2003. Mekong flood levels and Tonle Sap fish catches. In: Second International Symposium on the Management of Large Rivers for Fisheries, p. 1-13.

Ziv G, Baran E, So N, Rodriguez-Iturbe I, Levin SA. 2012. Tradingoff fish biodiversity, food security, and hydropower in the Mekong River Basin. Proc Natl Acad Sci USA 109: 5609-5614.

Cite this article as: Chan B, Ngor PB, So N, Lek S. 2017. Spatial and temporal changes in fish yields and fish communities in the largest tropical floodplain lake in Asia. Ann. Limnol. - Int. J. Lim. 53: 485-493 